\title{
РАЗВИТИЕ СЕЛЬСКОХОЗЯЙСТВЕННОГО ПРОИЗВОДСТВА С ИСПОЛЬЗОВАНИЕМ МЕХАНИЗМА ГОСУДАРСТВЕННО-ЧАСТНОГО ПАРТНЕРСТВА
}

\author{
(c) 2019 Мазлоев Виталий Зелимханович \\ доктор экономических наук, профессор, Заслуженный деятель науки РФ \\ Федеральный научный центр аграрной экономики и социального развития сельских \\ территорий - Всероссийский научно-исследовательский институт экономики \\ сельского хозяйства, Россия, Москва \\ E-mail: mazloevv@mail.ru
}

\begin{abstract}
Рассматриваются вопросы, раскрывающие экономическое содержание, сущность и особенности применения механизма государственно-частного партнерства (ГЧП) в сельскохозяйственном производстве на примере Забайкальского края. На основе достаточно глубокого анализа деятельности сельхозтоваропроизводителей различных организационно-правовых форм и масштабов производства показаны преимущества ГЧП в аграрном секторе, способствующие повышению инвестиционной привлекательности отрасли.
\end{abstract}

Ключевые слова: инвестиции, государственно-частное партнерство, сельскохозяйственное производство, хозяйственный механизм.

Изначально неоднозначное, а на наш взгляд, сомнительное стремление Российской Федерации во Всемирную торговую организации, и наконец, вступление в нее, а затем введение по отношению к нашей стране экономических санкций и ответные меры, ограничивающие ввоз продовольственных товаров из достаточно большого числа государств мира, поставили экономику страны в экстраординарные условия, что вынуждает принимать решения, адекватные создавшейся ситуации и способствующие выходу из нее.

Надо сказать, что государством в этом направлении сделаны определенные шаги, в частности Государственной программой развития сельского хозяйства и регулирования рынков сельскохозяйственной продукции, сырья и продовольствия на 2013-2020 гг. частично некоторые требования ВТО были учтены, то есть реализуются конкретные экономические рычаги государственного воздействия как: несвязанная поддержка производителям растениеводческой продукции, возмещении части затрат на уплату страховой премии, гранты в рамках некоторых целевых программ (Начинающий фермер и др.). Однако все эти меры имеют паллиативный характер. Необходимо перейти от идеологии субсидий к ориентации на повышение доходности аграрного производства посредством экономических рычагов и методов, делающих его инве- стиционно привлекательным, а продукцию конкурентоспособной.

С этой целью следует идти по пути совершенствования всей системы хозяйственного механизма агропромышленного комплекса, особенно в части регулирования товарно-денежных отношений использования рыночных стоимостных инструментов. Дело в том, что в экстремальных условиях, а они у нас присутствуют, применение товарно-денежных отношений должно носить аналогичный характер, то есть иметь жесткую целенаправленность и в комплексе с государственным регулированием обеспечивать: планомерное регулирование количественных соотношений стоимостных категорий (планово-рыночные отношения); оказывать воздействие на хозяйственные интересы производителей продукта и его потребителей; добиваться максимизации совпадения целей государства и интересов товаропроизводителей. Именно этот элемент, думается, есть необходимость рассмотреть детальнее. Тем более, достаточно большая мировая практика стран с развитой рыночной экономикой говорит о высокой дееспособности и эффективности функционирования различных форм государственно-частного партнерства, которые способствуют развитию инновационной системы государства, обеспечивающие модернизацию его экономию в том числе и аграрного сектора. 
В рамках государственно-частного партнерства с целью повышения инвестиционной активности используются различные стимулирующие инструменты:

- предоставление участником преференций и льгот (налоги, кредиты);

- прямое финансирование (США, Франция);

- специальные национальные программы (Германия, США, Франция);

- предоставление беспроцентных ссуд (Швеция, Голландия);

- создание фондов (Германия, Франция, Швейцария).

Сотрудничество между государством и бизнесом (ГЧП) порождает целый ряд преимуществ:

- во-первых появляются дополнительные источники инвестиций;

- во-вторых формируется новая институциональная среда, дающая возможность совместной деятельности по проектированию и реализации этих проектов;

- в третьих, государство может принимать активное участие в организации и управлении государственно-частным партнерством. [3]

Несмотря на целый ряд этих и других факторов, говорящих в пользу ГЧП в нашей реальной действительности, особенно в агропродовольственной сфере оно еще находится в стадии становления, правда некоторые шаги в этом направлении были предприняты, в частности приняты три Федеральных закона: «Об особых экономических зонах в Российской Федерации» от 22 июля 2005 г. № 116-Ф3, «О концессионных соглашениях» от 21 июля 2005 г. № 115 -ФЗ и «О государственно-частном партнерстве, муниципально-частном партнерстве в Российской Федерации» от 13 июля 2015 г. № 224-Ф3, что послужило толчком для создания некоммерческого партнерства «Национальный центр развития государственно-частного партнерства». Инициатором учреждения этого института явились крупные банки и различные бизнес-структуры $[8,9,10,11]$.

Следует отметить, что на сегодняшний день в сельскохозяйственном производстве страны есть уже некоторый опыт ГЧП, в частности это Забайкальский край.

В мае прошлого года было принято Распоряжение Правительства Российской Федерации от 3 мая 2018 г. № 849-р «Перечень мероприятий социально-экономического развития Забайкальского края, подлежащих реализации в 2018-
2025 годах в приоритетном порядке», в котором отдельным пунктом выделено «Увеличение объемов производства продукции растениеводства и животноводства акционерного общества «Племенной завод «Комсомолец».

В соответствии с этим документом объем инвестиций на первом этапе проекта составит 340,4 млн. руб.

Необходимо отметить особенность этой организации. АО «Племенной завод «Комсомолец» работает в Забайкальском крае Дальнего Востока с 2014 года. Оно было создано на частные инвестиции на базе обанкротившегося государственного предприятия ФГУП «Племзавод «Комсомолец».

В соответствии со сложившейся территориально-отраслевой структурой агропромышленного производства края приоритетными направлениями сельскохозяйственного производства определены мясное животноводство (основные подотрасли: мясное скотоводство, овцеводство, коневодство), молочное скотоводство, зерно- и кормопроизводство. С социальной точки зрения, развитие овцеводства, табунного коневодства северного оленеводства позволит в большей степени обеспечить занятость населения края, поддерживая традиционный уклад его жизни. Экспортонно-ориентированными видами сельскохозяйственной продукции в среднесрочной перспективе могут стать шерсть, маслосемена рапса и продукция его переработки, племенной молодняк, в долгосрочной - мясо.

Обеспечение устойчивого конкурентоспособного развития растениеводства обуславливает постоянное совершенствование и внедрение новых технологий выращивания сельскохозяйственных культур (адаптивно-ландшафтных, почвозащитных, влагосберегающих, а также ресурсо- и энергосберегающих), способствующих получению максимального количества экологически чистой продукции при наименьших затратах труда и средств; развитие селекции и семеноводства; техническое перевооружение отрасли; совершенствование размещения и структуры производства зерна и кормов.

В животноводстве наряду с ориентацией на преимущественное использование накопленного племенного и породного потенциала сельскохозяйственных животных, применение уже имеющихся технологий, дополнительные ресурсы должны быть направлены на совершенствование материально-технической базы кормо- 
производства, за счет которого будет обеспечен основной прирост продукции.

Предприятие активно и успешно занимается выращиванием зерновых и масличных культур, а также развивает животноводство (овцеводство и разведение крупного рогатого скота). В 2015 году спустя год после запуска сельскохозяйственного производства был получен урожай в размере 1.2 тыс. тонн рапса и 2.1 тыс. тонн зерновых. В 2018 году урожай зерновых увеличился в 4 раза, рапса - в 10 раз.

АО «ПЗ «Комсомолец» планирует реализовать масштабный проект по комплексному развитию растениеводства, предполагающий выращивание сельскохозяйственных культур (рапс, овес, ячмень), пользующихся огромным спросом в странах АТР, и стать одним из лидирующих предприятий по выращиванию рапса среди российских производителей.

В ходе производства компания строго соблюдает технологию севооборота для повышения урожайности сельскохозяйственных культур. Продукция выращивается из семян российского производства без генной модификации и является экологически чистой.

Проект АО «ПЗ «Комсомолец» располагает достаточным потенциалом, чтобы стать одним из лидеров сельскохозяйственной отрасли в России. Компания также может быть одним из ведущих экспортеров с учётом большого спроса на зерновые культуры в странах Азиатско-тихоокеанского региона. В 2016 году было подписано соглашение с партнёром из КНР о поставке урожая 2017 года.

Цели расходования привлекаемых средств:

- закупка российской с/х техники;

- закупка семян российского производства без содержания ГМО;

- введение в с/х оборот 104 тыс. га залежных земель (104 тыс. га занимают площадь больше, чем 200 тыс. футбольных полей);

$\mathrm{AO}$ «ПЗ Комсомолец» динамично развивается, где реализуется перспективный инвестиционный проект «Увеличение объемов производства продукции растениеводства АО «Племенной завод «Комсомолец» за счет вовлечения в оборот сельскохозяйственных угодий». Реализация данного инвестиционного проекта соответствует таким определенным приоритетам в Госпрограмме развития с.-х. на 2013-2020 гг., как развитие племенного животноводства, мелиорации земель сельскохозяйственного назначения, вве- дение в оборот неиспользуемой пашни и других категорий сельскохозяйственных угодий; сохранение трудовых ресурсов, повышение уровня продовольственной безопасности. Реализация проекта направлена на повышение продовольственной безопасности Забайкальского края и конкурентоспособности сельскохозяйственной продукции, повышение финансовой устойчивости сельскохозяйственных товаропроизводителей.

В результате реализации первого этапа инвестиционного проекта было произведено 42 тыс тонн зерна твердых сортов, 22,6 тыс тонн маслосемян рапса, 22,7 тонн говядины, 36,3 тонн баранины, 33 тонны шерсти, 446 голов племпродажи овец.

Заметны результаты государственно-частного партнерства и в отрасли молочного животноводства Забайкальского края.

Основными производителями молока в Забайкальском крае являются ЛПХ, в которых уже исчерпаны резервы роста производства и зачастую они не могут обеспечить молочные комбинаты требуемым качеством молока необходимого для современного производства молочной продукции. Проведенное исследование и результаты анализа показали, что в Забайкальском крае рост объемов производства молока возможен за счет вертикальной и горизонтальной интеграции: преобразования ЛПХ (92,5\% произведенного молока приходится на долю ЛПХ в Забайкальском крае, в то время как по регионам России данный показатель не превышает 52\%) в фермерские хозяйства с последующей их кооперацией, создание нового и (или) возобновление крупнотоварного производства молока в сельскохозяйственных организациях (1,3\% произведенного молока приходиться на долю сельскохозяйственных организаций в Забайкальском крае, в то время как в среднем по регионам России данный показатель составляет 49\%).

Надо отметить, что переход на крупнотоварное производство молока в Забайкальском крае позволит использовать для животноводства Забайкальского края в полной мере имеющиеся инструменты государственной поддержки развития молочного производства (гранты, субсидии, дотации, льготные кредиты на пополнение оборотных средств и на реализацию инвестиционных проектов).

В настоящее время имеющийся размер государственной поддержки молочного скотовод- 
ства в размере 124722,6 тыс. рублей согласно подпрограммы 9 «Развитие молочного скотоводства» госпрограммы «Развитие сельского хозяйства и регулирование рынков сельскохозяйственной продукции, сырья и продовольствия на 2014-2020 годы» не оказывает значительного влияния на развитие молочного скотоводства в сельскохозяйственных организациях Забайкальского края и не сможет кардинально улучшить ситуацию в молочном производстве. При этом большая часть господдержки приходится на мелкотоварные производства молока.

По состоянию на 1 января 2018 года из 30 грантополучателей 2017 года, 18 реализовали свои инвестиционные проекты, остальные - находятся в стадии их выполнения. Крестьянскими (фермерскими) хозяйствами с помощью грантовой поддержки приобретено 428 голов крупного рогатого скота. По оперативным данным реализовано сельскохозяйственной продукции на сумму 26,1 млн. рублей. Приобретено 30 ед. тракторов различных модификаций и марок, 5 ед. грузовых специализированных автомобилей, 69 ед. навесной и прицепной техники,19 ед. оборудования для производства молока.

Для наращивания объемов производства молока в крае необходимо перейти от мелкотоварного производства (ЛПХ и КФХ) к крупнотоварному в сельскохозяйственных организациях. В крае это позволит рационально использовать имеющийся ресурсный потенциал с целью наращивания объемов производства, осуществления импортозамещения как в сельском хозяйстве, так и на рынке продовольствия с последующим выходом молока и молочной продукции забайкальских товаропроизводителей на экспорт в Китай и другие страны Азии.

По экспертной оценке на реализацию этих целей для развития молочного скотоводства Забайкальском крае потребуется увеличить ежегодный объем государственной поддержки из федерального бюджета на сумму 350 млн. руб. (дотации на производство, субсидирование про- центной ставки по кредитам и возмещение прямых затрат в рамках инвестиционного проекта) и объем инвестиций в молочное скотоводство на сумму 1,15 млрд. руб. (эта сумма равна затратам на создание мегофермы с поголовьем от тысячи голов). Соответственно в Забайкальском крае уже к 2025 году поголовье коров сможет вырасти на 5 тыс. гол и увеличится производство молока на 14,5 тыс. тонн в год (в настоящее время дефицит баланса потребления молока в крае составляет в среднем 12 тыс. тонн в год). Край с 2025 года будет иметь профицит молока и может стать одним из крупных экспортеров молочной продукции в регионе.

Обязательным условием повышения эффективности и конкурентоспособности агропромышленного комплекса является привлечение и подготовка квалифицированной рабочей силы, в том числе молодых специалистов. Для создания и освоения новых технологий в агропромышленном комплексе необходимо совершенствование системы аграрного образования и подготовки специалистов-технологов и кадров массовых профессий для села, прежде всего механизаторов, для работы на новой высокопроизводительной, компьютеризированной технике.

В этом направлении реализуется мероприятие по созданию ресурсных центров подготовки специалистов для агропромышленного комплекса, учитывающих принцип зональных систем ведения растениеводства и животноводства. Кроме того необходимо развивать партнерство между аграрными образовательными учреждениями и сельхозтоваропроизводителями с использованием прямых договоров на подготовку специалистов различных уровней.

В итоге можно сказать, что государственно-частное партнерство в аграрном секторе достаточно многоаспектно, имеет достаточно широкий спектр использования, его эффективность высока и доказывает реальную возможность обеспечить продовольственную безопасность государства.

\section{Библиографический список}

1. Буздалов И.Н. Российское село и крестьянство в тисках монопольного окружения.- М.: ГНУ ВСТИСП Россельхозакадемии. - 2013 г.- 312 с.

2. Мазлоев В.З., Озерова М.Г. Экономический механизм аграрного сектора в условиях членства России в ВТО // Экономика сельскохозяйственных и сельскохозяйственных организаций. - 2015. - № 7. - Стр. 11-17.

3. Мазлоев B.3., Хайруллина О.И. Государственно-частное партнерство по технической модернизации мясного скотоводства // Экономика сельскохозяйственных и сельскохозяйственных организаций. - 2016.№ 9.- Стр. 28-34. 
4. Национальная экономика и обеспечение продовольственной безопасности в условиях интеграции и глобализации / под ред. Э.Н. Крылатых, В.З. Мазлоева.-М.: ИНФРА - М, 2015.- 240 с.

5. Об утверждении национального доклада о ходе и результатах реализации в 2016 году Государственной программы развития сельского хозяйства и регулирования рынков сельскохозяйственной продукции, сырья и продовольствия на 2013-2020 годы [Электронный ресурс].- Режим доступа: http:/government.ru/ docs/27573/, свободный.- Загл. с экрана.-Яз. рус., англ.

6. Официальные данные Федеральной службы статистики [Электронный ресурс]. Режим доступа: http://www. gks.ru, свободный.- Загл. с экрана. - Яз. рус., англ.

7. Указ Президента РФ от 30 января 2010 г. № 120 «Об утверждении Доктрины продовольственной безопасности Российской Федерации».

8. Федеральный закон «Об особых экономических зонах в Российской Федерации» от 22 июля 2005 г. № 116Ф3

9. Федеральный закон «О концессионных соглашениях» от 21 июля 2005 г. № 115-Ф3

10. Федеральный закон «О государственно-частном партнерстве, муниципально-частном партнерстве в Российской Федерации» от 13 июля 2015 г. № 224-Ф3

11. Национальный центр развития государственно-частного партнерства [Электронный ресурс].- Режим доступа: http://pppcenter.ru 